\title{
PARADOKS DESENTRALISASI PERUMAHAN DI INDONESIA STUDI KASUS KOTA PALEMBANG DAN KOTA PEKALONGAN
}

\author{
Mahditia Paramita \\ Program Studi Studi Kebijakan \\ Sekolah Pascasarjana Universitas Gadjah Mada \\ Email: hrc.jogja@gmail.com \\ Atyanto Dharoko \\ Fakultas Teknik Universitas Gadjah Mada \\ Muhajir Darwin dan Yeremias T. Keban \\ Fakultas Ilmu Sosial dan Politik Universitas Gadjah Mada
}

\begin{abstract}
Housing decentralization not only positions housing sector as regional obligatory, but also triggers public expectations upon the improvement of housing conditions. Various weaknesses of centralized system that full of generalization in housing policy makes decentralized system is interpreted as an innovative renewal process. However, the central government still does a lot of intervention toward housing program. Limitation happens to local government such as limitation in housing finance, weakness in coordination ability, and less established of local bureaucracy makes intervention from central government in housing program financed by APBN always dominates. The least contribution from local government on public housing sector in decentralization era creates paradox. It is caused by the Ministry of Public Housing (Kemenpera) that cannot perform fully as substitutional institution role in managing housing in local area. Kemenpera position as ministerial cluster 3 makes them does not have representative office in local area. Thus, there will be potential of a repeat experience in the past, in form of generalization in housing policy, that complicates the housing problems itself.
\end{abstract}

Keywords: Paradox, Decentralization Public Housing, Local Government.

\begin{abstract}
ABSTRAK
Desentralisasi perumahan selain memosisikan bidang perumahan sebagai urusan wajib daerah, juga memicu berkembangnya ekspektasi publik terhadap perbaikan kondisi perumahan. Berbagai kelemahan sistem sentralisasi perumahan yang sarat akan generalisasi kebijakan membuat sistem desentralisasi dimaknai sebagai proses pembaharuan inovatif. Akan tetapi, pada implementasinya, pemerintah pusat masih melakukan banyak intervensi dalam program perumahan. Limitasi pemerintah daerah seperti keterbatasan finansial pembiayaan perumahan, lemahnya kemampuan koordinasi, dan kurang matangnya birokrasi daerah membuat intervensi pemerintah pusat dalam program perumahan yang dibiayai APBN selalu mendominasi.Belum maksimalnya kontribusi pemerintah daerah di bidang perumahan pada era desentralisasi justru menimbulkan paradoks. Hal ini dikarenakan Kementerian Perumahan Rakyat (Kemenpera) tidak dapat menjalankan peran substitusi kelembagaan pengelola
\end{abstract}


perumahan di daerah secara maksimal. Posisi Kemenpera sebagai kementerian kluster 3 (tiga) membuat Kemenpera tidak memiliki kantor perwakilan di daerah. Dengan demikian, justru akan ada potensi terulangnya pengalaman masa lalu, yaitu generalisasi kebijakan perumahan, yang mempersulit problema perumahan itu sendiri.

Kata Kunci: Paradoks, Desentralisasi, Perumahan, Pemerintah Daerah.

\section{PENGANTAR}

Perumahan merupakan bagian dari kebutuhan dasar sehingga menjadi aspek yang sulit dipisahkan dari penyelenggaraan kebijakan publik baik di level pusat maupun daerah. Secara konstitusional, posisi perumahan sebagai bagian dari kebutuhan dasar warga negara telah diatur dalam UUD 1945. Sedangkan pada perspektif sosiologi keluarga, rumah menjadi unsur penting bagi perkembangan keluarga karena di dalamnya terjadi proses pembelajaran sosiologis seluruh anggota keluarga (Person Talcot, 2008: 24).Konsep sosiologi keluarga ini menunjukkan pandangan dari perspektif akademis mengenai arti penting rumah bagi masyarakat, sehingga layak dikategorikan sebagai kebutuhan primer.

Kehadiran UU No. 1 Tahun 2011 tentang Perumahan dan Kawasan Permukiman menjadi bukti pengakuan pemerintah terhadap pentingnya fungsi rumah sebagai kebutuhan pokok warga negara. Melalui regulasi tersebut, pemerintah mengatur pola penanganan perumahan sebagai salah satu upaya akselerasi pembangunan dan peningkatan kesejahteraan sosial. Secara regulatif, posisi bidang perumahan sebagai urusan wajib pemerintah daerah juga telah dipertegas dalam PP No. 38 Tahun 2007 tentang Pembagian Urusan Pemerintahan antara Pemerintah, Pemerintah Daerah Provinsi, dan Pemerintah Daerah Kabupaten/Kota. Dengan demikian, sudah ada dasar hukum yang tegas yang harus dijadikan pedoman bagi pemerintah daerah untuk melaksanakan peran aktif di bidang perumahan pada era desentralisasi.
Pada era desentralisasi, perumahan menjadi aspek yang harus didesentralisasikan. Hal ini dikarenakan posisi perumahan sebagai bidang yang sangat strategis bagi masyarakat sehingga perlu partisipasi peran pemerintah daerah. Sesuai dengan mekanisme regulasi desentralisasi yang dianutdiIndonesia, pemerintah daerah dalam proses desentralisasi perumahan secara empiris dapat berperan menyelenggarakan urusan perumahan sebagai urusan wajib daerah. Artinya, kepala daerah beserta seluruh jajaran SKPD memiliki kewajiban untuk menyelenggarakan pelayanan di bidang perumahan serta aktif melaksanakan inovasi dalam kebijakan perumahan di era desentralisasi. Dengan demikian, ada potensi pencapaian efisiensi dan efektivitas dalam desentralisasi perumahan, mengingat terpusatnya pengelolaan perumahan hanya akan menimbulkan proses generalisasi yang sangat tidak sesuai dengan kondisi di berbagai daerah yang heterogen seperti Indonesia.

Ada banyak ekspektasi yang secara rasional muncul menyikapi pilihan untuk melaksanakan desentralisasi perumahan. Hal ini disebabkan oleh peluang terciptanya percepatan proses penyelenggaraan kebijakan serta pelayanan publik di bidang perumahan. Pemerintah daerah selalu dipandang sebagai pihak yang lebih memahami problem perumahan di daerah dibandingkan dengan pemerintah pusat. Oleh karena itu, desentralisasi perumahan seakan-akan telah menjanjikan adanya reformasi pelayanan publik di bidang perumahan secara berkesinambungan. Menurut Ajarinen dan Peltonen, ekspektasi publik yang tinggi terhadap penyelenggaraan desentralisasi merupakan sesuatu yang sudah given dan terjadi secara masif tanpa memperhitungkan tipikal desentralisasi yang dianut (Ajarinenn Joni dan Jaakko Peltonen, 2008:4-5). Dengan demikian, dapat dikatakan bahwa munculnya ekspektasi publik yang tinggi terhadap desentralisasi perumahan di Indonesia merupakan hal yang bersifat alamiah dan tidak dapat dihindari. 
Pada urusan wajib penanganan perumahan, pemerintah daerah dituntut untuk aktif dalam perumusan kebijakan yang terkait dengan tanah, infrastruktur, konstruksi, pembiayaan, dan keamanan bermukim atau secure tenure. Regulasi mengenai urusan perumahan sebagai urusan wajib daerah ini secara regulatif memosisikan pemerintah kabupaten/kota sebagai lokus utama desentralisasi perumahan. Di sisi lain, pemerintah provinsi menjalankan kewajiban sebagai wakil dari pemerintah pusat di daerah dan berwenang menyelenggarakan koordinasi pembimbingan teknis dengan pemerintah kabupaten/kota.

Secara konseptual, kesuksesan penyelenggaraan desentralisasi perumahan dapat diidentifikasi dari terciptanya iklim pemerintah pusat yang katalis dan pemerintah daerah yang mampu menangani berbagai kompleksitas problema perumahan. Artinya, penilaian ideal terhadap kesuksesan penyelenggaraan desentralisasi perumahan dilihat dari pencapaian pemerintah pusat dan daerah.Sedangkan dalam konteks desentralisasi perumahan di Indonesia, kriteria kesuksesan desentralisasi perumahan dapat dilihat dari tingkat kapasitas pemerintah daerah untuk mengatasi masalah klasik berupa backlog, rumah tidak layak huni (RTLH), dan permukiman kumuh.Selain itu, terdapat pula penilaian kriteria kesuksesan desentralisasi perumahan di Indonesia yang diidentifikasi melalui tingkat kapasitas pemerintah daerah dalam melakukan upaya pembagian peran di bidang perumahan dengan pemerintah pusat.

Bagi pemerintah daerah, desentralisasi perumahan dapat berarti hal yang baik dalam mempercepat pembangunan perumahan, tetapi di lain sisi juga dapat memperlambat pembangunan perumahan di daerah. Kondisi ini dikarenakan keberhasilan program tergantung pada prioritas perumahan bagi pemerintah daerah dan kapasitas pemerintah daerah dalam menyelesaikan permasalahan yang dihadapi. Hal ini membuat terciptanya paradoks dalam penyelenggaraan desentralisasi perumahan. Tulisan ini merupakan hasil analisis yang dilakukan untuk menjawab pertanyaan: "mengapa paradoks dihadapi oleh pemerintah daerah dan apakah desentralisasi perumahan masih dibutuhkan untuk menyelesaikan permasalahan perumahan yang terjadi di daerah?"

Desentralisasi pada tataran implementasi seringkali diidentikkan dengan otonomi daerah.Bahkan, tidak jarang desentralisasi dimaknai sebagai padanan kata (sinonim) dengan otonomi daerah. Meskipun antara desentralisasi dan otonomi daerah memiliki kedekatan makna leksikal, tetapi keduanya secara konseptual berbeda.Desentralisasi dan otonomi daerah merupakan suatu dikotomi (Bardhan Pranab, 2002). Desentralisasi lebih menekankan pada aspek penyerahan wewenang dari pemerintah pusat ke daerah. Sementara itu, otonomi daerah dapat dipahami sebagai kebebasan untuk menyelenggarakan rumah tangga sendiri bagi pemerintah daerah sehingga dapat dilihat bahwa desentralisasi selalu muncul lebih awal dibandingkan dengan otonomi daerah. Hal ini dikarenakan kewenangan pemerintah daerah untuk menyelenggarakan pemerintahannya secara otonom baru muncul pasca ada penyerahan wewenang dari pemerintah pusat kepada pemerintah daerah.

Secara teoritikal dalam studi tentang desentraliasasi, kelompok pendukung desentralisasi selalu menilai bahwa desentralisasi berpotensi mampu meningkatkan kekuasaan pemerintahan daerah (Falleti Tulia, 2005). Melalui desentralisasi, pemerintah daerah berkesempatan penuh untuk melakukan berbagai hal yang menyangkut permasalahan publik dan kepentingan publik (public affair and public interest). Desentralisasi telah menjadi bentuk devolving kekuasaan penyelenggaraan kebijakan dan pelayanan publik. Hal ini membuat kerap kali transformasi dari sistem sentralisasi menjadi desentralisasi ditanggapi secara euphoria oleh pemerintah daerah. Padahal, faktanya peningkatan devolving di era desentralisasi tidak hanya dialami oleh pemerintah daerah melainkan juga pada tataran masyarakat melalui pengakuan terhadap partisipasi masyarakat. 
Pengakuan terhadap eksistensi partisipasi masyarakat menjadi bukti empiris peningkatan demokratisasi dalam pelaksanaan desentralisasi. Selain itu, secara umum penyelenggaraan desentralisasi di negara-negara berkembang berimplikasi pula terhadap meningkatnya respons permintaan terhadap penyelenggaraan pelayanan pemerintahm (Azfar Omar, 1999). Peningkatan respons pelayanan pemerintah ini sekaligus menunjukkan bahwa era desentralisasi di negara-negara berkembang telah diikuti dengan kesadaran masyarakat untuk memenuhi kebutuhan pelayanan dasar.

Konsentrasi penyelenggaraan kebijakan dan pelayanan publik pada pemerintah daerah di era desentralisasi membuat ekspektasi publik terhadap perbaikan kebijakan dan pelayanan publik berfokus pada skema pemerintahan daerah. Hal ini menimbulkan pemusatan penilaian publik terhadap kinerja pemerintah daerah. Dengan demikian, ada semacam dorongan motivasi psikologis dari pemerintah daerah untuk memaksimalkan kinerjanya di era desentralisasi. Menurut Finger dan Kunneke, kriteria kesuksesan pemerintah daerah di era desentralisasi dapat diupayakan melalui kemampuan pemerintah daerah dalam policy entrepreneurship (Finger, Matthias dan Rofl Kunnuke, 2008). Pemerintah daerah yang mampu mengembangkan policy entrepreneurship memiliki kemampuan adaptasi yang tinggi untuk menghadapi kompleksitas problematika kebijakan dan pelayanan publik di era desentralisasi.

Ada dikotomi pemahaman tentang pemerintah daerah antara kaum Marxian dan liberalis. Pemerintah daerah oleh penganut aliran Marxian dinilai sebagai sebuah institusi yang hanya sekadar mereproduksi kehadiran negara dalam rangka menciptakan kondisi yang mendukung bagi proses akumulasi capital (Dunleavy, 1980). Pada pandangannya tersebut, kaum Marxian secara skeptis melihat bahwa pemerintah daerah merupakan kepanjangan tangan pemerintah pusat, menjadi corong bagi keputusan-keputusan pusat, dan tidak memiliki otonomi untuk mengatur rumah tangganya sendiri. Sementara itu, kaum liberalis melihat bahwa pemerintah daerah dijalankan secara demokratis dengan mengedepankan aspirasi masyarakat daerah sehingga menyokong proses demokratisasi lokal serta menjadi roh baru bagi terciptanya demokratisasi di level nasional (Smith, 1985: 19-37). Penganut aliran liberalis meyakini secara positif bahwa pemerintah daerah berdiri bukan sekadar sebagai jelmaan dari pemerintah pusat, melainkan sebagai fasilitator penciptaan demokrasi di daerah.

Secara struktural, pemerintah daerah adalah entitas penyelenggara pemerintahan daerah yang secara hierarki-struktural berelasi vertikal dengan pemerintah pusat. Pemahaman tersebut merupakan pemahaman umum yang nyaris tanpa perdebatan kecuali dari kaum Marxian. Hal ini dikarenakan kaum Marxian melihat tidak ada pemisahan entitas antara pemerintah pusat dan pemerintah daerah sehingga tidak ada istilah hubungan antara pemerintah pusat dan pemerintah daerah dalam kacamata kaum Marxian (Pratikno, 2007: 27). Meskipun bukan dideskripsikan sebagai jabatan ex-officio atau jabatan rangkap antara penyelenggara pemerintah pusat dan pemerintah daerah, keyakinan kaum Marxian terhadap ketiadaan pemisahan entitas antara pemerintah pusat dan pemerintah daerah didasarkan pada pandangan yang melihat bahwa pemerintah daerah sekadar sebagai implementator kebijakan pemerintah pusat tanpa memberikan respons terhadap aspirasi akar rumput masyarakat daerah. Pandangan penganut Marxian ini seolah ingin menegaskan posisi pemerintah pusat sebagai policy maker dan posisi pemerintah daerah sebagai policy implementor secara mutlak.

Pada proses desentralisasi, pemerintah daerah memiliki serentetan limitasi yang mengakibatkan potensi kegagalan pemerintah daerah untuk mengatasi masalah kebijakan dan pelayanan publik (Garret Geoffrey dan Jonathan Rodden, 2001:2). Limitasi pemerintah daerah ini berpotensi menimbulkan paradoks pada proses desentralisasi. Tidak terbebasnya 
pemerintah daerah dari kepentingan politik merupakan salah satu latar belakang melekatnya limitasi dalam penyelenggaraan pemerintahan daerah di era desentralisasi. Perkembangan politik di daerah seringkali membuat pemerintah daerah sulit terpisah dari unsur politis. Terlebih secara praktis beberapa jabatan dalam struktur pemerintahan daerah didesain sebagai jabatan politis.

Pada tataran implementasi, tidak jarang limitasi pemerintah daerah dijadikan sebagai celah oleh pemerintah pusat untuk melakukan intervensi. Karena ketika pemerintah daerah kuat, peluang masuknya intervensi pemerintah pusat menjadi lebih kecil, dan begitu pula sebaliknya. Akan tetapi selain dipengaruhi oleh kuat tidaknya pemerintah daerah, intervensi pemerintah pusat juga sangat dipengaruhi oleh kompleksitas stakeholders organisasi birokrasi pemerintah daerah. Pada konsep stakeholders mapping, banyak dibahas bahwa semakin kompleks stakeholders yang terlibat dan berperan dalam struktur birokrasi pemerintah daerah akan semakin menyulitkan masuknya intervensi dari pemerintah pusat. Sebaliknya, ketika kompleksitas struktur birokrasi pemerintah daerah semakin sederhana dan minim jumlah stakeholders-nya, intervensi pemerintah pusat semakin mudah masuk.

Sejalan dengan pandangan konsep stakeholders mapping, Robbin menegaskan ada pengaruh tingkatan eselon birokrasi pemerintah daerah terhadap intervensi pemerintah pusat (Robbins Stephen, 2007:114). Menurut Robbin, intervensi pemerintah pusat lebih mudah masuk pada level eselon birokrasi pemerintah daerah yang lebih rendah. Hal ini karena pada level eselon birokrasi pemerintah daerah yang lebih rendah, kompleksitas stakeholdersnya juga lebih rendah. Dalam perspektif tersebut, Robbin juga menambahkan adanya perdebatan efisiensi dan efektivitas struktur organisasi pemerintah daerah dalam jangka pendek dan panjang di era desentralisasi. Kondisi ini mengingat intervensi pemerintah pusat pada pemerintah daerah selalu dikaitkan dengan efisiensi dan efektivitas baik dalam jangka pendek maupun jangka panjang. Demikian juga dengan dampak desentralisasi yang juga dapat dilihat manfaatnya dalam jangka pendek maupun jangka panjang.

Istilah perumahan publik lazim digunakan di berbagai literatur karena perumahan merupakan bagian dari kebutuhan dasar publik. Perumahan dapat digunakan sebagai indikator tingkat kesejahteraan sosial. Hal ini mengingat perumahan tidak pernah dapat dipisahkan dari aspek kemiskinan (Glaeser dan Gyurko, 2008: 17). Pada pandangannya tersebut, Glaeser dan Gyourko menyebutkan bahwa kemiskinan dapat diidentifikasi dari kepemilikan rumah, kondisi fisik rumah, kualitas lingkungan, dan sarana prasarana penunjang perumahan. Masyarakat miskin selalu identik dengan ketiadaan kemampuan akses hunian yang layak, kumuh, dan kurangnya sarana prasarana umum (PSU).

Keterkaitan perumahan dengan kemiskinan dan kesejahteraan sosial menunjukkan bahwa perumahan menjadi faktor penentu dalam kebijakan pembangunan. Hal ini membuat dinamika penyelenggaraan kebijakan perumahan sangat mempengaruhi kebijakan pembangunan. Menurut Melville dan Millan, jika perumahan dianggap sebagai bagian dari kebijakan pembangunan, maka peran pemerintah daerah di bidang perumahan dapat dipahami sebagai peran distribusi barang publik (Melville dan Mc Milan, 2007: 34). Dalam hal ini, pemerintah memiliki peran sebagai principle sedangkan masyarakat kelompok sasaran kebijakan perumahan merupakan agen pengguna. Peran principle di bidang perumahan dapat dijalankan pemerintah melalui kebijakan dan pelayanan publik.Dalam hal ini, selain sebagai agen pengguna dalam konteks kelompok sasaran, masyarakat turut berperan sebagai pihak yang berwenang memberikan persepsi kepuasan terhadap penyelenggaraan kebijakan dan pelayanan perumahan publik yang dilaksanakan oleh pemerintah.

Di era desentralisasi, kejelasan pembagian peran antara pemerintah pusat dan 
daerah dalam pengelolaan perumahan menjadi kunci utama suksesnya desentralisasi perumahan. Kejelasan pembagian peran tersebut harus dilakukan secara integral, baik dalam penanganan aspek tanah, pembiayaan, infrastruktur, konstruksi, maupun secure tenure. Dengan demikian, desentralisasi perumahan dapat menyajikan perbaikan kebijakan bagi masyarakat selaku warga pengguna pelayanan publik di bidang perumahan.

Secara konseptual, kegagalan penyelenggaraan desentralisasi selalu dikaitkan dengan kurang optimalnya kapasitas pemerintah daerah. Hal ini dikarenakan dalam proses penyelenggaraan desentralisasi, pemerintah daerah menjadi lokus utama. Berbagai limitasi pemerintah daerah yang tidak segera diatasi pada era desentralisasi mencerminkan bahwa pemerintahan daerah belum dilaksanakan secara dynamic governance. Menurut Neo dan Chen, dynamic governance merupakan suatu konsep yang dapat dijadikan sebagai rujukan untuk meningkatkan kapasitas organisasi pemerintah dan membuat organisasi pemerintah tersebut mengalami kenaikan tingkat responsivitasnya terhadap kebutuhan publik (Neo Boon Siong dan Geraldine Chen, 2007: 86). Demikian juga dalam konteks penyelenggaraan pemerintahan daerah di era desentralisasi, dynamic governance sangat dibutuhkan sebagai tahap penguatan kapasitasnya.

Pemahaman menuju proses dynamiclocal governance, aspek yang perlu diperhatikan oleh penyelenggara pemerintah daerah adalah restrukturisasi kelembagaan. Tidak dapat dipungkiri bahwa struktur kelembagaan birokrasi pemerintah daerah sangat mempengaruhi daya lentingnya (bounce power) terhadap berbagai intervensi eksternal, termasuk intervensi dari pemerintah pusat. Pertahanan diri terhadap berbagai intervensi perlu dilakukan oleh pemerintah daerah sebagai upaya antisipasi berbagai kepentingan para aktor untuk mengaburkan makna desentralisasi yang sedang dilaksanakan. Meskipun ada konsep yang menyebutkan bahwa organisasi pemerintah daerah tidak dapat bebas nilai dan dapat menggunakan berbagai intervensi sebagai referensi input kebijakan seperti yang dikemukakan oleh Rabin dan Wachhaus (Rabbin Jack dan T Aaron Wachhaus, 2007: 134). kekuatan daya lenting terhadap intervensi perlu dikembangkan secara integral oleh organisasi pemerintah daerah.

\section{PEMBAHASAN \\ Nilai Penting Desentralisasi Perumahan}

Pada konteks penyelenggaraan kebijakan perumahan di Indonesia, desentralisasi perumahan menjadi hal yang penting. Melalui proses desentralisasi perumahan, pemerintah daerah memiliki peluang untuk memosisikan bidang perumahan sebagai urusan wajib daerah. Dengan demikian, pemerintah daerah dituntut berperan aktif dalam memenuhi kebutuhan masyarakat terhadap akses perumahan.Peran strategis pemerintah daerah sebagai pihak yang memiliki kewajiban mengurus perumahan di era desentralisasi secara regulatif tidak hanya diatur dalam UU No. 1 Tahun 2011, melainkan juga sebelumnya telah ditegaskan dalam PP No. 38 Tahun 2007.

Desentralisasi perumahan merupakan terobosan untuk menyelesaikan tantangan sentralisasi yang telah terjadi selama dekade lalu. Kecenderungan generalisasi program perumahan yang dilakukan oleh pemerintah pusat dalam pengalaman sentralisasi perumahan telah menciptakan berbagai kegagalan program. Bahkan, kegagalan program akibat generalisasi penanganan perumahan justru menyisakan berbagai permasalahan baru. Tidak adanya keberlanjutan program, terbengkalainya kondisi fisik perumahan dan PSU yang tidak sesuai dengan kebutuhan masyarakat lokal, serta pasifnya pemerintah daerah menjadi bukti empiris adanya sisa-sisa permasalahan yang diwariskan dari sistem sentralisasi perumahan di masa lalu. 
Secara empiris, desentralisasi memungkinkan adanya variasi pengelolaan perumahan dari masing-masing daerah dengan karakteristik yang heterogen. Ada peluang diselenggarakannya program perumahan yang berbeda di masing-masing daerah yang disesuaikan dengan kebutuhan lokal dan karakteristik masyarakat setempat. Dengan demikian, dapat dilihat perbedaan mencolok antara sistem sentralisasi dan desentralisasi perumahan. Lebih responsifnya sistem desentralisasi perumahan dalam menghadapi tantangan heterogenitas variasi kebutuhan perumahan antardaerah membuat potensi generalisasi penanganan perumahan sangat kecil dibanding potensi penanganan perumahan secara generatif dalam sistem sentralisasi.

Kelebihan lain yang dimiliki oleh sistem desentralisasi perumahan berdasarkan pengalaman penyelenggaraan kebijakan perumahan di Indonesia adalah efisiensi dan efektivitas birokrasi. Desentralisasi perumahan dapat dikatakan lebih efisien dan efektif dibanding sentralisasi perumahan karena penyelenggaraan pelayanan publik di bidang perumahan akan lebih cepat pasca dalam mekanisme desentralisasi perumahan. Hal ini dikarenakan posisi masyarakat sebagai warga pengguna pelayanan publik dan kelompok sasaran kebijakan perumahan lebih dekat dengan pemerintah daerah dibandingkan dengan pemerintah pusat. Selain itu, pemerintah daerah merupakan pihak yang berhadapan dengan berbagai problema di daerah sehingga memiliki kelebihan dalam pemahaman setiap detail permasalahan perumahan di daerah dibandingkan dengan pemerintah pusat.

Kriteria kesuksesan desentralisasi perumahan dapat dicapai melalui kemampuan pemerintah daerah menjalin relasi yang harmonis dengan pemerintah pusat. Selain itu, ada stabilitas tata kelola birokrasi yang ditandai dengan penanganan secara aman walaupun terjadi friksi antar SKPD (Satuan Kerja Perangkat Daerah) dan konflik di pemerintah pusat dan daerah.
Secara empiris, kemampuan pemerintah daerah dalam mempertahankan hubungan yang baik dengan pemerintah pusat maupun menjaga stabilitas tata kelola birokrasi merupakan suatu keniscayaan meskipun terdapat berbagai limitasi yang melekat. Hal ini sekaligus mendebat pandangan Garret dan Rodden yang menyebutkan bahwa limitasi pemerintah daerah selalu membuat mereka mengalami kesulitan untuk menghindari konflik horizontal antar SKPD maupun konflik vertikal dengan pemerintah pusat (Garret dan Rodden 2001: 2).

Utopia penerapan sistem desentralisasi perumahan adalah terbentuknya kemampuan pemerintah daerah yang berperan sebagai katalis dalam percepatan pembangunan perumahan.Kemampuan katalis pemerintah daerah dapat diidentifikasi dari tingkat kapasitas pemerintah daerah untuk berkontribusi dalam penurunan angka backlog, angka RTLH, dan luasan permukiman kumuh. Dalam desentralisasi perumahan, pemerintah daerahjuga memiliki keleluasaan yang besar untuk merumuskan inovasi dalam kebijakan perumahan. Dengan demikian, paper ini lebih menyepakati perspektif kaum liberalis tentang peranan pemerintah daerah yang bersifat otonom dalam desentralisasi perumahan (Smith,1985: 19-37).

Kritik yang umum dialamatkan dalam sistem desentralisasi perumahan adalah inefisiensi jangka pendek yang lazim terjadi khususnya ketika pemerintah daerah berupaya melakukan reformasi penanganan perumahan melalui inovasi kebijakan perumahan yang dirumuskannya. Seringkali, inovasi pemerintah daerah dalam kebijakan perumahan seperti yang dilakukan Pemerintah Kota Palembang dan Pemerintah Kota Pekalongan menimbulkan inefisiensi berupa pemborosan penggunaan sumber daya. Kesulitan pemerintah daerah untuk menghindari inefisiensi sumber daya tidak jarang menuai banyak kritik dan sikap skeptis. Akan tetapi, di sisi lain yang perlu digarisbawahi adalah meskipun telah terjadi inefisiensi dalam jangka pendek pada mekanisme desentralisasi perumahan, harus 
diakui juga bahwa ada nilai efisiensi dan efektivitas yang dapat dicapai dalam jangka panjang.

\section{Desentralisasi Perumahan Pemerintah Kota Palembang Kebijakan Perumahan Pemerintah Kota Palembang}

Penegasan regulasi yang memosisikan perumahan sebagai urusan wajib daerah dalam UU No. 1 Tahun 2011 dan PP No. 38 Tahun 2007 dimaknai oleh Pemerintah Kota Palembang sebagai kewajiban pemerintah daerah untuk memprioritaskan bidang perumahan dalam kebijakan pembangunannya. Prioritas perumahan dalam kebijakan pembangunan secara empiris telah dilakukan oleh Pemerintah Kota Palembang di era desentralisasi. Melalui dokumen perencanaan RPJMD dan RP4D dapat diidentifikasi tingginya skala prioritas Pemerintah Kota Palembang terhadap bidang perumahan. Di Kota Palembang, bidang perumahan tidak sekadar diposisikan sebagai proses kegiatan pembangunan fisik, tetapi juga dijadikan sebagai salah satu langkah akselerasi untuk meningkatkan kesejahteraan sosial.

Akan tetapi, pada pembiayaan perumahan, Pemerintah Kota Palembang masih dihadapkan pada masalah keterbatasan finansial yang menjadi limitasi dalam pembiayaan program unggulan perumahan. Masih bergantungnya keuangan daerah terhadap dana perimbangan di era desentralisasi membuat Pemerintah Kota Palembang tidak memiliki cukup anggaran untuk pembiayaan penanganan perumahan dari sumber APBD. Keterbatasan kemampuan pembiayaan ini membuat Pemerintah Palembang melaksanakan inovasi dalam kebijakan pendanaan untuk menarik berbagai sumber dana guna pembiayaan perumahan di era desentralisasi. Inovasi dalam pendanaan perumahan tersebut dilakukan dengan cara pelibatan BUMD PT SP2J, serta melakukan koordinasi program perumahan yang didanai oleh pemerintah pusat.
Berdasarkan hasil wawancara dengan Subdis Cipta Karya Dinas PU Cipta Karya dan Perumahan Kota Palembang pada 13 Januari 2013 dan verifikasi data pada 22 Maret 2014, diperoleh deskripsi upaya Pemerintah Kota Palembang untuk menjalin relasi yang baik dengan pemerintah pusat. Upaya ini dilakukan untuk memastikan keberhasilan program penanganan perumahan yang sumber pembiayaannya berasal dari APBN seperti program BSPS (Bantuan Stimulan Perumahan Swadaya). Upaya menjalin hubungan yang harmonis dengan pemerintah pusat, Pemerintah Kota Palembang bersikap aktif dalam proses koordinasi bimbingan teknis yang melibatkan unsur Kementerian Perumahan Rakyat (Kemenpera), Pemerintah Provinsi Sumatera Selatan, dan Pemerintah Kota Palembang.

Secara empiris, perhatian Pemerintah Kota Palembang terhadap bidang perumahan pada tataran kebijakan diekspresikan dengan pembentukan jargon "city without slum". Jargon tersebut menunjukkan visi Pemerintah Kota Palembang untuk mereduksi berbagai kekumuhan perkotaan di era desentralisasi. Dalam tataran operasional, visi "city without slum" diwujudkan dalam pembangunan perumahan yang fokus pada perbaikan rumah, bedah rumah, dan rehabilitasi rumah. Sedangkan terkait masalah permukiman, Lakip Kota Palembang Tahun 2012 menjelaskan bahwa upaya peningkatan penataan kawasan permukiman dilaksanakan dengan tahapan: pengembangan perumahan, lingkungan sehat perumahan, pemberdayaan komunitas perumahan, perbaikan perumahan akibat bencana alam atau sosial, peningkatan kesiagaan dan pencegahan bahaya kebakaran, pengelolaan areal permukiman, penerangan jalan dan utilitas, pengelolaan persampahan yang memadai, serta pengelolaan ruang terbuka hijau.

Inovasi Pemerintah Kota Palembang dalam kebijakan perumahan yang dilakukan melalui pelibatan BUMD PT SP2J dilakukan untuk meminimalisir risiko kredit macet yang ditimbulkan oleh KPR yang diajukan 
oleh MBR.Melalui dasar hukum Peraturan Presiden No. 70 Tahun 2012 tentang Perubahan Kedua Atas Peraturan Presiden No. 54 Tahun 2010 tentang Pengadaan Barang/Jasa Pemerintah dalam pasal 38 ayat 5 huruf h, PT SP2J ditunjuk oleh Pemerintah Kota Palembang untuk melaksanakan upaya pengelolaan kawasan perumahan sebagai perantara perjanjian kredit perumahan antara pihak bank penyelenggara KPR dengan pihak MBR dan warga miskin selaku pihak pengaju kredit, serta menarik cicilan harian untuk masyarakat. Sebelum dilibatkan dalam kebijakan perumahan di Kota Palembang, secara empiris PT SP2J merupakan BUMD yang didirikan dengan tujuan untuk meningkatkan pertumbuhan ekonomi daerah dan mereferensi para investor untuk lebih tertarik menanam modal di Kota Palembang.

Meskipun dalam pelaksanaan peranan sebagai lembaga intermediary penjamin risiko KPR, pada tahapan implementasi PT SP2J ini memiliki daya lenting (bounce power) terhadap intervensi pemerintah pusat. Daya lentingnya dapat dilihat dari kemampuannya bertahan terhadap upaya intervensi pemerintah pusat untuk merestrukturisasi PT SP2J. Restrukturisasi tersebut dilakukan dengan menghilangkan fungsinya di bidang perumahan dan mengembalikannya ke fungsi semula sebagai lembaga pemasaran dan promosi penanaman modal sesuai Perda No.4 Tahun 2006 tentang Pendirian Perseroan Terbatas (PT) Sarana Pembangunan Palembang Jaya pada tahun 2012. Intervensi pemerintah pusat dilatarbelakangi oleh krisis finansial PT SP2J akibat kesenjangan cadangan anggaran yang dimiliki dengan tingginya jumlah kredit macet KPR MBR di Kota Palembang.

Daya lenting PTSP2J terhadap intervensi pemerintah pusat menjadi hal yang menarik karena PT SP2J merupakan organisasi yang hanya dikelola oleh 2 stakeholders. Sehingga, dapat dikatakan bahwa PT SP2J tidak memiliki kompleksitas stakeholders yang rumit. Kondisi empiris ini mendebat pandangan teori stakeholders mapping yang mempercayai bahwa organisasi dengan kompleksitas stakeholder rendah (ditandai dengan sedikitnya jumlah stakeholders) memiliki daya lenting yang lemah terhadap intervensi eksternal. Kemampuan daya lenting PT SP2J dalam menghadapi intervensi pemerintah pusat menunjukkan bahwa meskipun hanya terdiri dari 2 stakeholders, yaitu pihak swasta dan pemerintah daerah yang terdiri dari RUPS (Rapat Umum Pemegang Saham) dan Pemerintah Kota Palembang, PT SP2J tetap memiliki daya lenting yang kuat.

\section{Paradoks Desentralisasi Perumahan di Kota Palembang}

Secara empiris, ada kontradiksi yang terjadi pada pembangunan perumahan di Kota Palembang di era desentralisasi. Meskipun dalam tataran konseptual telah banyak disebutkan berbagai implikasi positif kebijakan desentralisasi perumahan serta mekanisme desentralisasi perumahan tersebut telah dilaksanakan, Pemerintah Kota Palembang masih menghadapi berbagai permasalahan.Tingginya angka backlog, jumlah RTLH, dan masih luasnya permukiman kumuh menjadi masalah di bidang perumahan bagi Kota Palembang pada era desentralisasi. Berdasarkan data statistik, tercatat angka backlog di Kota Palembang sebesar 136.049 unit pada tahun 2012. Untuk kondisi kekumuhan permukiman, Bappeda Kota Palembang mencatat permukiman kumuh tersebar di 47 kawasan di Kota Palembang secara sporadis.

Tingginya angka backlog, jumlah RTLH, dan luasan permukiman kumuh menunjukkan bahwa desentralisasi perumahan belum secara otomatis berimplikasi terhadap bebasnya daerah dari permasalahan perumahan.Tersisanya problema perumahan di Kota Palembang tidak bisa dikatakan sebagai warisan sistem sentralisasi perumahan sebelum tahun 1998. Hal ini dikarenakan secara empiris berbagai program unggulan seperti BSPS, bedah rumah, dan rehabilitasi rumah telah dilakukan di Kota Palembang di era desentralisasi.Meskipun ada penurunan 
angka backlog, RTLH, dan luasan permukiman kumuh sebagai implikasi programprogram unggulan tersebut, secara empiris belum menghilangkan secara total ketiga permasalahan itu. Kondisi ini menyiratkan pemahaman bahwa perbaikan pembangunan perumahan bukan menjadi aspek given dari penerapan sistem desentralisasi perumahan.

Permasalahan menjadi semakin rumit ketika Pemerintah Kota Palembang memiliki keterbatasan pembiayaan perumahan. Program-program penanganan perumahan yang dibiayai APBD Kota Palembang hanya mampu meng-cover kelompok sasaran dengan jumlah yang terbatas. Hal ini menimbulkan kecilnya implikasi perbaikan yang dikontribusikan oleh program-program penanganan perumahan yang dibiayai APBD Kota Palembang seperti program bedah rumah dan program rehabilitasi rumah.

Dengan melakukan penelaahan lebih mendalam, paper ini mengarisbawahi adanya 3 (tiga) fakta terkait keterbatasan Pemerintah Kota Palembang dalam pembiayaan perumahan. Pertama, permasalahan keterbatasan kemampuan pembiayaan perumahan jamak dihadapi oleh pemerintah daerah di level kabupaten/kota pada era desentralisasi. Dengan kata lain, permasalahan keterbatasan kemampuan pembiayaan bukan masalah yang hanya terjadi di tataran Pemerintah Kota Palembang.

Kedua, kondisi keterbatasan kemampuan dalam pembiayaan perumahan di era desentralisasi membuat Pemerintah Kota Palembang mengalami kesulitan untuk menghindari ketergantungan pembiayaan program perumahan dari pemerintah pusat. Meskipun memberikan implikasi perbaikan kondisi perumahan yang lebih besar dibandingkan dengan program yang dibiayai oleh APBD, program pembangunan perumahan yang sumber pembiayaannya dari APBN justru memicu paradoks desentralisasi perumahan.

Ketiga, terdapat peluang intervensi yang lebih besar dari pemerintah pusat terhadap pemerintah daerah pada program pembangunan perumahan yang dibiayai oleh pemerintah pusat. Seperti yang terjadi pada program BSPS, intervensi pemerintah pusat mendominasi proses agenda setting. Ada hambatan Pemerintah Kota Palembang dalam menghindari intervensi pemerintah pusat dalam perumusan program pembangunan perumahan yang sumber pendanaannya dari APBN. Meskipun pada proses perumusan inovasi dalam program BSPS, Pemerintah Kota Palembang mampu mendominasi pada tahapan formulasi karena kekuasaan yang dimiliki, intervensi pemerintah pusat praformulasi dalam agenda setting tetap tidak bisa dihindari.

Ketergantungan Pemerintah Kota Palembang terhadap program penanganan perumahan yang dibiayai oleh pemerintah pusat di era desentralisasi dapat dilihat dari 2 (dua) sudut pandang.Tidak dapat dipungkiri bahwa Pemerintah Kota Palembang menghadapi kesulitan untuk meningkatkan sumber penerimaan daerah yang berujung pada keterbatasan kemampuan pembiayaan perumahan. Di sisi lain, kondisi keuangan daerah ini muncul akibat desentralisasi fiskal yang tidak dilaksanakan secara integral dalam mekanisme desentralisasi pemerintahan di Indonesia. Mekanisme kebijakan desentralisasi yang diselenggarakan hanya terpusat pada desentralisasi politik dan mengabaikan desentralisasi fiskal (Davey, 1989: 223). Hal ini membuat paradoks desentralisasi perumahan menjadi semacam lingkaran setan (vicius cicle) bagi Pemerintah Kota Palembang.

Dalam desentralisasi perumahan di Kota Palembang, tidak dapat dipungkiri bahwa berbagai limitasi birokrasi Pemerintah Kota Palembang menghambat proses akselerasi perbaikan kebijakan perumahan. Kondisi ini juga memicu munculnya ide-ide konseptual tentang resentralisasi perumahan. Pada tataran praktis, resentralisasi perumahan di era desentralisasi bukan merupakan hal yang tabu. Namun, posisi Kemenpera sebagai kementerian kluster 3 (tiga) membuat Kemenpera selaku representasi pemerintah pusat di bidang perumahan mengalami hambatan resentralisasi perumahan. Sebagai 
kementerian kluster 3 (tiga), Kemenpera tidak memiliki kantor perwakilan di daerah sehingga berpotensi menghambat proses penanganan masalah perumahan. Bahkan bila dipaksakan adanya tindakan pengambilalihan penanganan perumahan oleh Kemenpera justru menimbulkan pengulangan kemungkinan generalisasi kebijakan seperti pengalaman sentralisasi perumahan sebelum tahun 1998.Dengan demikian, limitasi Pemerintah Kota Palembang dan posisi Kemenpera sebagai kementerian kluster 3 (tiga) membuat semakin kentaranya paradoks dalam desentralisasi perumahan di Kota Palembang.

\section{Desentralisasi Perumahan Pemerintah Kota Pekalongan Kebijakan Perumahan Pemerintah Kota Pekalongan}

Bagi Pemerintah Kota Pekalongan, penetapan regulasi UU No. 1 Tahun 2011 dan PP No. 38 Tahun 2007 terkait posisi bidang perumahan sebagai urusan wajib daerah ditanggapi dengan positif. Berdasarkan wawancara yang dilakukan padatanggal 5 Januari 2013 dan verifikasi data pada tanggal 24 Juni 2014, Kepala Bappermas Kota Pekalongan memaknai penetapan bidang perumahan sebagai urusan wajib daerah tersebut sebagai kewajiban Pemerintah Kota Pekalongan untuk mengarus utamakan bidang perumahan dalam kebijakan pembangunan daerah. Pada tataran implementasi, pengarusutamaan bidang perumahan dalam kebijakan pembangunan daerah Pemerintah Kota Pekalongan dapat dilihat dari RPJMD Kota Pekalongan yang memuat tujuan yang terkait dengan isu perumahan.Tujuan tersebut adalah "meningkatkan kualitas rumah tinggal, lingkungan permukiman, dan ketersediaan infrastruktur air bersih bagi masyarakat miskin".

Sebelum tahun 2013, Bappermas Kota Pekalongan menjadi organ birokrasi Pemerintah Kota Pekalongan yang berperan aktif dalam penanganan bidang perumahan. Kewenangan penanganan bidang perumahan oleh Bappermas Kota Pekalongan muncul secara given akibat perluasan cakupan tugas pokok dan fungsi kelembagaan Bappermas. Sebagai lembaga yang menangani bidang kesejahteraan masyarakat, Bappermas Kota Pekalongan memperluas makna peningkatan kesejahteraan masyarakat sebagai aspek yang juga harus mencakup kelayakan hunian sehingga memosisikan bidang perumahan sebagai salah satu tupoksinya.Hal ini membuat bidang perumahan tidak sekadar dimaknai sebagai bentuk pembangunan fisik,tetapi sebagai upaya pembangunan manusia melalui dorongan partisipasi masyarakat.

Seperti yang dialami oleh Pemerintah Kota Palembang, pada era desentralisasi, Pemerintah Kota Pekalongan juga masih dihadapkan pada limitasi kemampuan pembiayaan perumahan dari sumber APBD. Keterbatasan kemampuan pembiayaan membuat jangkauan program pembangunan yang dijalankan masih belum maksimal menuntaskan permasalahan klasik seperti backlog, RTLH, dan permukiman kumuh. Di sisi lain, keterbatasan kemampuan pembiayaan perumahan membuka peluang terbentuknya koordinasi antara Pemerintah Kota Palembang dengan pemerintah pusat dan kelompok-kelompok lain dalam sharing pendanaan maupun penyelenggaraan program perumahan yang didanai APBN.

Tingginya kompleksitas stakeholders yang terlibat dalam penanganan perumahan di Kota Pekalongan dimaknai oleh Pemerintah Kota Pekalongan dengan jargon "sapu lidi" yang didefinisikan sebagai serangkaian kerjasama berbagai aktor untuk membersihkan seluruh permasalahan yang menghambat pembangunan perumahan pada era desentralisasi. Istilah manajemen kroyokan kemudian dikembangkan sebagai mekanisme perumusan berbagai program unggulan di bidang perumahan. Penelitian ini menemukan adanya aspek menarik dari fenomena kompleksnya stakeholders dalam penanganan perumahan di Kota Pekalongan,yaitu selain melibatkan unsur Pemerintah Kota Pekalongan, Pemerintah Provinsi Jawa Tengah, pemerintah pusat, 
masyarakat, dan pihak swasta terdapat keberadaan kelompok intermediary yang turut berpartisipasi. Kelompok intermediary yang terlibat dalam penanganan perumahan di Kota Pekalongan adalah lembaga ekonomi mikro yang berpartisipasi memberikan stimulus bantuan kredit usaha kecil bagi kelompok sasaran kebijakan perumahan. Keterlibatan kelompok intermediary lembaga ekonomi mikro menjadi salah satu inovasi Pemerintah Kota Pekalongan untuk memastikan keberlanjutan program perumahan sekaligus memastikan ada upaya peningkatan kesejahteraan kelompok sasaran pasca implementasi program tersebut.

\section{Paradoks Desentralisasi Perumahan di Kota Pekalongan}

Di Kota Pekalongan, penerapan desentralisasi perumahan tidak secara otomatis menghapus seluruh kompleksitas permasalahan di bidang perumahan. Masih tingginya angka backlog, jumlah RTLH, dan luasan permukiman kumuh menjadi kondisi empiris yang membuktikan masih rumitnya permasalahan perumahan di Kota Pekalongan pada era desentralisasi. Kemiskinan masyarakat juga semakin memperparah permasalahan perumahan di Kota Pekalongan. Berdasarkan data dari Lakip Kota Pekalongan tahun 2013, dapat dilihat adanya keberadaan KK miskin sejumlah 22.913 atau 36,4\% dari jumlah KK Kota Palembang. Dari jumlah KK miskin tersebut, terdapat $5.068 \mathrm{KK}(22,12 \%)$ yang bertempat tinggal di RTLH. Kondisi ini dapat dikatakan sangat parah karena selain KK miskin, juga terdapat 800 PNS golongan rendah (golongan I dan II) dan 8.000 buruh yang mengalami permasalahan akses rumah layak huni. Bahkan dari jumlah tersebut, 465 PNS (58,12\%) dan 2.985 buruh $(37,35 \%)$ belum memiliki rumah.

Masih rumitnya permasalahan perumahan di Kota Pekalongan pada era desentralisasi menunjukkan bahwa desentralisasi tidak memberikan secara given perbaikan bagi bidang perumahan.Desentralisasi hanya menjadi momentum partisipasi aktif Pemerintah Kota Pekalongan untuk menangani berbagai permasalahan di bidang perumahan. Akan tetapi, ketika ada limitasi berupa keterbatasan kemampuan pembiayaan perumahan, maka ada berbagai hambatan yang menghantui upaya inovatif Pemerintah Kota Pekalongan dalam kebijakan perumahan di era desentralisasi.

Keterlibatan stakeholders secara kompleks dalam penanganan perumahan di Kota Pekalongan pada era desentralisasi menimbulkan dampak positif solusi pendanaan di tengah keterbatasan kemampuan pemerintah daerah terkait pembiayaan perumahan. Di sisi lain, keterlibatan multistakeholders justru menjadi bumerang karena ada banyak celah bagi kelompok-kelompok kepentingan untuk melakukan intervensi dalam berbagai program pembangunan perumahan di Kota Pekalongan. Berdasarkan hasil analisis yang dilakukan, penelitian ini menggarisbawahi adanya preferensi berbagai kelompok kepentingan khususnya pemerintah pusat untuk melakukan intervensi pada program perumahan yang didanai APBN.Sedangkan pada program perumahan di Kota Pekalongan yang dibiayai oleh APBD, Pemerintah Kota Pekalongan menjadi aktor yang dominan pada setiap tahapan perumusan program sehingga intervensi kelompok kepentingan dapat diminimalisir.

Dominasi pemerintah pusat pada tahapan agenda setting dan formulasi program BSPS dan pembangunan rusunawa di Kota Palembang menjadi bukti adanya intervensi terhadap Pemerintah Kota Pekalongan. Intervensi tersebut dilakukan oleh pemerintah pusat dalam penetapan kriteria kelompok sasaran, lokus program, dan mekanisme implementasi program. Lebih mudahnya intervensi pemerintah pusat masuk dalam penanganan perumahan di Kota Pekalongan yang lebih tinggi kompleksitas stakeholders-nya dibandingkan penanganan bidang perumahan di Kota Palembang melalui pelibatan BUMD PT SP2J sangat kontradiktif dengan pandangan teori stakeholders mapping. Teori stakeholders 
mapping meyakini bahwa semakin tinggi kompleksitas stakeholders, maka organisasi akan semakin sulit menerima intervensi. Pembelajaran dari kasus Kota Pekalongan menunjukkan hal yang berbeda karena justru intervensi pemerintah pusat sangat mudah masuk meskipun ada kompleksitas stakeholders yang tinggi di dalamnya. Aspek yang terlewat dari teori stakeholders mapping adalah pandangan yang melihat bahwa intervensi bersifat eksternal. Padahal seperti yang terjadi dalam penanganan perumahan di Kota Pekalongan era desentralisasi, intervensi justru dilakukan oleh aktor kepentingan yang menjadi bagian dari proses penanganan perumahan tersebut. Kondisi ini membuat terjadinya paradoks dalam desentralisasi perumahan di Kota Pekalongan.

Selain itu, terlalu cepatnya peralihan sistem sentralisasi perumahan ke sistem desentralisasi secara empiris juga memicu terjadinya konflik horizontal dalam organ birokrasi Pemerintah Kota Pekalongan. Euforia Pemerintah Kota Pekalongan dalam menghadapi desentralisasi perumahan menimbulkan konflik antara Bappermas, Dinas PU Cipta Karya, dan Bappeda. Terbentuk dikotomi perspektif kewenangan pengelolaan perumahan. Bappermas Kota Pekalongan memiliki penilaian bahwa perumahan merupakan bagian dari upaya kesejahteraan masyarakat sehingga masuk dalam lingkup tugas pokok dan fungsinya. Sementara itu, Dinas PU Cipta Karya dan Bappeda Kota Pekalongan memosisikan perumahan sebagai bidang pembangunan fisik yang memuat dampak kesejahteraan sosial. Konflik horizontal ini secara empiris mencapai klimaks pada tahun 2013 dengan pengalihan kewenangan pengelolaan perumahan dari Bappermas kepada Dinas PU Cipta Karya.

Masih kurang optimalnya kinerja Pemerintah Kota Pekalongan di bidang perumahan pada era desentralisasi sulit ditangani oleh resentralisasi perumahan. Hal ini karena posisi Kemenpera sebagai lembaga kementerian kluster 3 (tiga) membuat
Kemenpera kurang mampu berperan substitusi dalam manajemen pembangunan perumahan Kota Pekalongan. Sama halnya dengan yang terjadi di Kota Palembang, alternatif penyelesaian masalah berupa dijalankannya peran substitusi pengelolaan perumahan Kota Pekalongan oleh pemerintah pusat (Kemenpera) akan menimbulkan potensi terulangnya kembali pengalaman generalisasi kebijakan perumahan. Hal ini berakibat pada tidak terakomodirnya karakteristik identitas masyarakat Kota Pekalongan secara berkesinambungan.

\section{SIMPULAN}

Berdasarkan hasil analisis yang dilakukan, dapat ditarik tiga kesimpulan. Pertama, paradoks desentralisasi muncul karena adanya kondisi keterbatasan faktor penentu kesuksesan desentralisasi perumahan, serta pemerintah daerah masih belum matang sehingga membutuhkan peningkatan kemampuan menjadi policy entrepreneur. Di samping itu, juga diperlukan kesadaran penuh untuk meningkatkan kapasitas menentukan kebijakan yang tepat ketika terjadi perubahan tak terencana. Kematangan pemerintah daerah menjadi syarat mutlak untuk mereduksi kompleksitas paradoks desentralisasi perumahan. Hal ini karena kerapuhan mekanisme regulasi desentralisasi yang menimbulkan paradoks secara empiris dapat diminimalisir implikasi negatifnya jika pemerintah daerah memiliki kematangan birokrasi.

Kedua, desentralisasi perumahan diperlukan untuk memenuhi kompleksitas keragaman kebutuhan dan masalah perumahan di daerah, mempercepat proses pelayanan perumahan, dan mendorong efek akselerasi peningkatan kesejahteraan sosial. Desentralisasi perumahan menekankan peran strategis pemerintah daerah sehingga ada potensi pembenahan perumahan yang lebih baik dibandingkan dengan sistem sentralisasi perumahan. Pemerintah daerah merupakan bagian dari entitas daerah, lebih dekat dengan masyarakat umum khususnya kelompok sasaran, serta lebih 
memahami problema permasalahan di daerah. Dengan demikian, meskipun ada beberapa mekanisme desentralisasi yang pada proses implementasi menimbulkan paradoks, kesalahan (mistakes) tidak berada pada pilihan sistem desentralisasi perumahan, melainkan pada mekanisme desentralisasi perumahan yang dijalankan. Dengan demikian, perlu ada restrukturisasi mekanisme desentralisasi perumahan di Indonesia untuk mempersempit celah terbentuknya paradoks desentralisasi perumahan.

Ketiga, desentralisasi perumahan yang sukses adalah yang mampu mereduksi berbagai masalah perumahan yang dihadapi di daerah. Pemerintah daerah mampu berperan sebagai katalis dalam percepatan pembangunan perumahan melalui penurunan angka backlog, angka RTLH, dan luasan permukiman kumuh. Selain itu, diperlukan adanya kestabilan tata kelola birokrasi baik secara horizontal maupun vertikal. Walaupun terjadi friksi antar-SKPD dan konflik di pemerintah pusat dan daerah, tetapi dapat ditangani secara aman.

Studi kasus yang dipilih belum mampu mengkomparasikan hasil analisis desentralisasi dan sentralisasi perumahan karena penelitian ini memiliki limitasi. Selain itu, penelitian ini juga belum menyajikan komparasi antarvariansi mekanisme desentralisasi perumahan dari negaranegara lain. Dengan terbatasnya jumlah studi kasus dan jenis desentralisasi yang berbeda, penelitian ini membuka peluang dilakukannya penelitian lanjutan oleh para akademisi dan praktisi yang memiliki perhatian terhadap kebijakan desentralisasi perumahan.

\section{DAFTAR PUSTAKA}

Ajarinenn, Joni dan Jaakko Peltonen. 2008. Expectation Maximalization for Average Reward Decentralized POMDPs. Springer Link Papers Submid.

Azfar, Omar. 1999. Decentralization, Government and Public Services; The Impact of Institutional Arrangement. A Review of The Literature. Collece Park: IRIS Centre University of Maryland.

Bahl, Roy dan Jorge Martinez Vasquez. 2005. Sequencing Fiscal Decentralization. Georgia : Georgia State University.

Bardhan, Pranab. 2002. Decentralization of Governance and Development. Journal of Economic Perspective.Vol.16 No.4.

Dunleavy, P. 1980. "Social and Political Theory andThe Issues in Central-Local Relations". dalam Jones, GW. New Approaches to The Study of CentralLocal Government Relationships. Aldershot: Gower\& SSRC.

Falleti, Tulia G. 2005.A Sequential Theory of Decentralization and Its Effect on The Intergovernmental Balance Power; Latin American Case in Comparative Perspective. American Political Science Review.Vol.99 No.3.

Finger, Matthias dan Rofl Kunnuke. 2008. Exploring Socio-Technical Governance Regimes in Liberalizing Network Industries.Discussion paper series on the Coherence between institutions and technologies in infrastructures.

Garret, Geoffrey dan Jonathan Rodden. 2001. Globalization and Fiscal decentralization. Paper Prepared for delivery at the Conference: Globalization and Governance.

Glaeser E dan Gyurko J. 2008.Housing Supply and Housing Bubbles.Journal of Urban Economics Vol. 64 No. 2.

Gidden, Anthony. 2001.Sociology. Cambridge: Polity Press.

Melville dan Mc Milan. 2007. "A Local Perspective On Fiscal Federalism: Practices, Experiences, And Lessons From Industrial Countries dalam Fischer, Frank dkk. 2007. Handbook of Publik Policy Analysis. London: CRC Press.

Neo, Boon Siong dan Geraldine Chen. 2007. Dynamic Governance; Embedding 
Culture, Capabilities and Changes in Singapore.5TohTuckLink,Singapore: World Scientific Publishing.

Perason, Talcot. 2008. Sociological Perspective dalam Linsey, Linda. 2008. Gender Roles; A Sociological Perspective. Maryville University of St. Louis: Pearson Education Inc. p. 24.

PP No. 38 Tahun 2007 tentang Pembagian Urusan Pemerintahan Antara Pemerintah, Pemerintah Daerah Provinsi,dan Pemerintah Daerah Kabupaten/Kota.

Pratikno. 2007. "Pengelolaan Hubungan Antara Pusat dan Daerah". dalam Haris, Syamsuddin. DesentralisasiE Otonomi Daerah; Desentralisasi, DemokratisasiEAkuntabilitas Pemerintah Daerah. Jakarta: LIPI Press.
Rabbin Jack dan T Aaron Wachhaus. 2007. Civil Disobidience. Encyclopedia of Public Administration and Public Policy. Marcel Dekker: 2nd ED.

Razzolini, Laura. 2001. Editors' Report. Shoutern Economic Journal Vol. 75 No. 2.

Robbins, Stephen. 2007. Teori Organisasi. Edisi terjemahan. Jakarta: EGC.

Smith, BC. 1985. Decentralization; The Territorial Dimension of The State. London: George Allen\& Unwin.

Utomo, Warsito.2008. Administrasi Publik Baru Indonesia. Yogyakarta: Pustaka Pelajar.

UUD 1945, Amandemen Ke IV.

UU No. 32 Tahun 2004 tentang Pemerintahan Daerah.

UU No. 33 Tahun 2004 tentang Perimbangan Keuanagan antara Pemerintah Pusat dan Pemerintah Daerah.

UU No. 1 Tahun 2011 tentang Pembangunan Perumahan dan Kawasan Permukiman. 